\title{
A New and Facile Preparation of Optically Active Endo-Bicyclo [n,1,0] Hex(Hept)An-2-Ols by In Vitro Enzyme Catalysis
}

\author{
Farhi Halaïmia, Hichem Sadrik Kettouche* and Abdel Hafid Djerourou
}

\author{
Synthesis and Organic Biocatalysis Laboratory, Faculty of Science, Chemistry Department, Badji Mokhtar University, \\ P.B. 12, Annaba, 23000, Algeria
}

\begin{abstract}
Various optically active endo-bicyclo [n,1,0]hex(hept)an-2-ols, were synthesized from the cyclopropanation of cyclopent(hex)en-2-ols and followed by the transesterification of the isoprenyl hexanoate in the presence of Novozym ${ }^{\circledR}$ as catalyst. The enantioselectivity is more satisfactory with endo-bicyclo [4,1,0] heptan-2-ols (E > 60) than with endobicyclo $[3,1,0]$ hexan-2-ols $(\mathrm{E}<20)$.
\end{abstract}

Keywords: Cyclopropanation, endo-bicyclo $[\mathrm{n}, 1,0]$ hex(hept)an-2-ols, enzymatic resolution, Novozym ${ }^{\circledR}$.

\section{INTRODUCTION}

Enzyme catalysis has been one of the most useful methods for the preparation of enantiomerically pure compounds. Numerous studies have indicated the application of enzymes to prepare synthons for use in asymmetric synthesis and many reviews on this subject have been published recently [1]. Enzymes such as Candida antarctica lipase B (Novozym 435), Pig liver esterase (PLE), Pseudomonas cepacia lipase (PCL), Candida rugosa lipase (CRL), Burkholderia cepacia lipase (BCL), and Aspergillus oryzae protease (AOP) have been used. Enzymes can be employed in the resolution of alcohols and esters and many examples have been reported in the literature [1].

The enzymatic synthesis of optically active bicyclo [n,1,0]alkan-2-ols should be interesting in order to prepare natural compound with such a feature [2] or analogs, but these compounds are also interesting intermediates for the synthesis of various types of compuds with one or several stereogenic carbon centers.

Cleavage of the $\mathrm{C}^{1}-\mathrm{C}^{\mathrm{n}+3}$ or $\mathrm{C}^{\mathrm{n}+2}-\mathrm{C}^{\mathrm{n}+3}$ cyclopropanic bond of bicyclo [n.1.0]alkan-2-ols allows the synthesis of various types of compounds bearing one or several chiral atoms. Substitution of the hydroxyl group by a homolytically cleavable substituent allows the synthesis of cycloalkenes with at least one stereogenic carbon atom by cleavage of the $\mathrm{C}^{1}-\mathrm{C}^{\mathrm{n}+3}$ cyclopropane bond. Thus, the preparation of enantiomerically enriched bicyclo [n,1,0]alkan-2-ols derivatives [3] should give an access to various types of compounds in an optically active form.

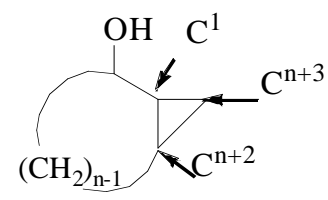

\footnotetext{
*Address correspondence to this author at the Synthesis and Organic Biocatalysis Laboratory, Faculty of Science, Chemistry Department, Badji Mokhtar University, P.B. 12, Annaba, 23000, Algeria;

E-mail: sadrik9@yahoo.fr
}

Optically active endo-bicyclo [n,1,0]alkan-2-ols derivatives are generally prepared by hydroxyl directed cyclopropanation of optically active cycloalk-2-en-1-ols compounds [4] (Scheme 1) or by diastereoselective addition of nucleophiles to enantiomerical enriched endo-bicyclo $[\mathrm{n}, 1,0]$ alkan-2-ols [5]. Recently we have reported the lipasecatalyzed kinetic resolution of racemic endo-bicyclo $[\mathrm{n}, 1,0]$ hexan-2-ols and that of the endo-bicyclo $[\mathrm{n}, 1,0]$ heptan-2-ols.

In this paper we have focused on the preparation of optically active endo-bicyclo [n,1,0] hexan-2-ols $\mathbf{4 b}, \mathbf{d}-\mathbf{e}, \mathbf{g}[6]$ (Scheme 2) and optically active endo-bicyclo $[\mathrm{n}, 1,0]$ heptan2-ols 4'a-g [7,8] (Scheme 3) by enzymatic resolution in order to show the influence of the substituent on the selectivity. This type of reaction was run at $37^{\circ} \mathrm{C}$ in tertbutylmethylether with an acylating agent (isopropenyl hexanoate).

\section{RESULTS AND DISCUSSION}

Since 4 and 4' were unknown, we turned our attention towards their synthesis and their enzymatic resolution. Racemic compounds $\mathbf{4}$ and $\mathbf{4}$ ' were obtained by reaction under air [4] of cyclopent (hex)-2-en-1-ols $\mathbf{3}$ and 3' with the reagent obtained by the addition of $\mathrm{ClCH}_{2} \mathrm{I}$ to $\mathrm{Et}_{2} \mathrm{Zn}$ [9]. The required cyclopent(hex)enols $\mathbf{3}$ and $\mathbf{3}$ ' were prepared by reduction of the corresponding cyclopent(hex)-2-en-1-ones 2 and 2' with $\mathrm{NaBH}_{4}$ in the presence of $\mathrm{CeCl}_{3} .7 \mathrm{H}_{2} \mathrm{O}$ [10]. Also 2 and 2' were obtained by treatment of 3-ethoxycyclopent (hex)-2-en-1-ones 1 [11] and 1' [11] with $\mathrm{RMgX}$ [12] or RLi [13] followed by an aqueous treatment. It is noteworthy that the compounds 3-ethoxycyclopent(hex)-2-en-1-ones $\mathbf{1}$ and $\mathbf{1}$ ' were prepared as described in the literature [11] by treatment of commercially available cyclopent(hex)ane-1,3-diones as the starting material with ethanol in the presence of $p$ toluensulfonic acid (Scheme 1).

Firstly, the resolution of racemic endo-bicyclo $[3,1,0]$ hexan-2-ols $\mathbf{4 b}, \mathbf{d}-\mathbf{e}, \mathbf{g}$, performed by employing Novozym $^{\circledR}$ as catalyst in the presence of an acyl donor (isopropenyl hexanoate) in tert-BuOMe as hydrophobic organic solvent at $37^{\circ} \mathrm{C}$ [6] (Scheme 2), was found to give unsatisfactory $E$-values $(E<20)$ (Table 1). These results show 


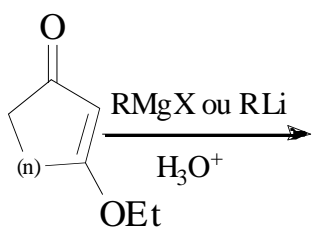<smiles>[R]C1=CC(=O)CC1</smiles>

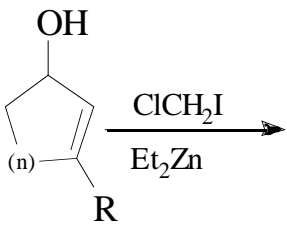<smiles>[R]C12CCC(O)C1C2</smiles>

$\begin{array}{lll}\mathrm{n}=1 & 1 & 2 \mathrm{~b}, \mathrm{~d}-\mathrm{e}, \mathrm{g} \\ \mathrm{n}=2 & 1^{\prime} & 2^{\prime} \mathrm{a}-\mathrm{g}\end{array}$

3b,d-e,g
3'a-g

$4 \mathrm{~b}, \mathrm{~d}-\mathrm{e}, \mathrm{g}$

$\mathrm{n}=2 \quad 1$

a-g

a: $\mathrm{R}=\mathrm{H}, \mathbf{b}: \mathrm{R}=\mathrm{CH}_{3}, \mathbf{c}: \mathrm{R}=\mathrm{C}_{2} \mathrm{H}_{5}, \mathbf{d}: \mathrm{R}=\mathrm{C}_{4} \mathrm{H}_{9}, \mathbf{e}: \mathrm{R}=\mathrm{C}_{6} \mathrm{H}_{13}, \mathbf{f}: \mathrm{R}=\mathrm{C}_{11} \mathrm{H}_{23}, \mathbf{g}: \mathrm{R}=\mathrm{CH}_{2} \mathrm{Ph}$

Scheme 1.

that it is difficult to isolate $\mathbf{4 b}, \mathbf{d}-\mathbf{- e}, \mathbf{g}$ and oblige us to restrict the examples to be studied. It was observed that the use of substrates with small group provide low-selective reactions (Table 1, entry 1). Better results were obtained when substrates $\mathbf{4}$ are substituted with butyl group (Table 1, entry 2 ). Therefore, the structure of the substrates plays a great role on enzymatic selectivity.

With a moderately enantioselective enzyme $(E<20)$, the reaction carries to well over $50 \%$ conversion to get unreacted enantiomer of high optical purity at the cost of acylated enantiomer of lower optical purity. The enantioselectivity of Novozym ${ }^{\circledR}$ is largely dependent on the structure of substrate as formulated by Kazlauskas [14]: most lipases show $(R)-$ selectivity toward simple secondary alcohols carrying one small and one relatively larger substituent at the hydroxyl methane center, and the selectivity in general increases with an increase in the size difference between two substituents. The small size of the substituent limits the reactivity of substrate toward lipase.

Also an enzymatic methods afforded an alternative and effective way for the synthesis of optically active endobicyclo [4,1,0]heptan-2-ols -ols 4**a-g [7,8] (Scheme 3).

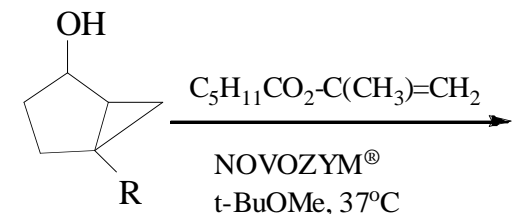

rac-endo-4
The results of the transesterification of racemic endobicyclo [4,1,0]heptan-2-ols 4'a-g with tert-BuOMe in the presence of lipase from candida Antarctica $\left(\right.$ Novozym $\left.^{\circledR}\right)$ as catalyst reported in Table 2 show that the $E$ values observed for Novozym ${ }^{\circledR}$ catalyzed reaction of the corresponding 4'a-g with isopropenyl hexanoate were between 60 and 800 .

Except the reactions of $\mathbf{4}^{\prime} \mathbf{b}$, for all the other attempts, the enantioselectivity and the reaction rate were simultaneously higher. As expected in this type of Kinetic resolution, it is possible to isolate the product or the unreacted substrate with a good ee by running the reaction at about $50 \%$ conversion.. So these reaction conditions seem more attractive from a synthetic point of view.

In case the enzyme is highly enantioselective $(E=200$ or greater) (Table $\mathbf{2}$, entry $4,6,7$ ), the resolution reaction in general is stopped at nearly $50 \%$ conversion to obtain both unreacted enantiomers and acylated enantiomers in enantiomerically enriched forms.

Generally, enzyme-catalyzed transesterifications were stopped at about $50 \%$ conversion by removing the enzyme by filtration, then bicycloalkyl hexanoates $5^{*}$ and $\mathbf{5}$ * and unreacted bicycloalkanols $4 *$ and $4^{\prime} *$ were separated by

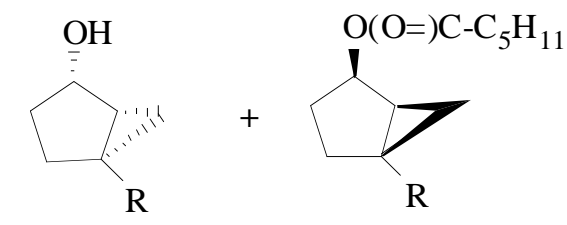

$4 *$

$5 *$

Scheme 2.

Table 1. Novozym ${ }^{\circledR}$ - Catalyzed Transesterification of Isopropenyl Hexanoate with Endo- Bicyclo [4,1,0] Hexan-2-Ols

\begin{tabular}{|c|c|c|c|c|c|c|c|c|c|c|c|}
\hline \multirow{2}{*}{$\mathbf{N}^{\circ}$} & \multirow{2}{*}{$\mathbf{R}$} & \multirow{2}{*}{ Substra } & \multirow{2}{*}{ Time (h) } & \multicolumn{3}{|c|}{ Alcohol 4* } & \multicolumn{3}{|c|}{ Ester 5* } & \multirow{2}{*}{$\mathbf{C}$} & \multirow{2}{*}{$\mathbf{E}$} \\
\hline & & & & Yied $(\%)^{\mathrm{a}}$ & {$[\alpha]_{\mathrm{D}}^{20}$} & $\mathrm{ee}_{\mathrm{ss}}(\%)^{\mathrm{b}}$ & Yield $(\%)^{\mathrm{a}}$ & {$[\alpha]_{D}^{20}$} & $\mathbf{e e}_{\mathrm{pp}}(\%)^{\mathrm{b}}$ & & \\
\hline 1 & $\mathrm{CH}_{3}$ & $4 b$ & 1.5 & 48 & $-23(1.1)$ & 54 & 40 & $+28(1.1)$ & 67 & 0.45 & 8 \\
\hline 2 & $\mathrm{CH}_{3}-\left(\mathrm{CH}_{2}\right)_{3}-$ & $4 d$ & 2 & 52 & $-39(0.9)$ & 71 & 44 & $+49.7(0.8)$ & 80 & 0.47 & 19 \\
\hline 3 & $\mathrm{CH}_{3}-\left(\mathrm{CH}_{2}\right)_{5^{-}}$ & $4 e$ & 1.30 & 42 & $-63(1.3)$ & 69 & 47.5 & $+57(0.7)$ & 75 & 0.48 & 14 \\
\hline 4 & $\mathrm{CH}_{3}-\left(\mathrm{CH}_{2}\right)_{10}$ & $4 g$ & 1.8 & 47 & $-43(1.1)$ & 64 & 49 & $+58(0.9)$ & 67 & 0.49 & 10 \\
\hline
\end{tabular}

${ }^{\mathrm{a}}$ Isolated yield.

${ }^{\mathrm{b}}$ Enantiomeric excess (ee) was determined by CGC. 


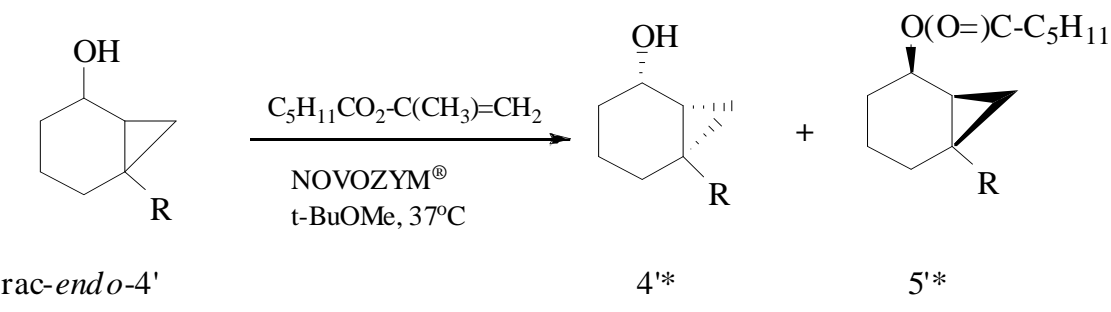

Scheme 3.

Table 2. Novozym $^{\circledR}$ - Catalyzed Transesterification of Isopropenyl Hexanoate with Endo- Bicyclo [4,1,0]Heptan-2-Ols

\begin{tabular}{|c|c|c|c|c|c|c|c|c|c|c|c|}
\hline \multirow{2}{*}{$\mathbf{N}^{\circ}$} & \multirow{2}{*}{$\mathbf{R}$} & \multirow{2}{*}{ Substrat } & \multirow{2}{*}{ Time (h) } & \multicolumn{3}{|c|}{ Alcohol 4\% } & \multicolumn{3}{|c|}{ Ester 5* } & \multirow{2}{*}{$\mathbf{C}$} & \multirow{2}{*}{$\mathbf{E}$} \\
\hline & & & & Yields $(\%)^{\mathrm{a}}$ & {$[\alpha]_{\mathrm{D}}^{20}$} & $\mathrm{ee}_{\mathrm{s}}(\%)^{\mathrm{b}}$ & Yields $(\%)^{\mathrm{a}}$ & {$[\alpha]_{D}^{20}$} & $\mathrm{ee}_{\mathrm{p}}(\%)^{\mathrm{b}}$ & & \\
\hline 1 & $\mathrm{H}$ & 4'a & 0.5 & 41 & $-57(2.0)$ & $75^{\mathrm{b}}$ & 42 & $+75(1.3)$ & $95^{\mathrm{b}}$ & 0.44 & 88 \\
\hline 2 & $\mathrm{CH}_{3}$ & 4'b & 2 & 48 & $-71(0.9)$ & $96^{\mathrm{c}}$ & 44 & $+65(0.8)$ & $88^{\mathrm{c}}$ & 0.52 & 61 \\
\hline 3 & $\mathrm{CH}_{2}-\mathrm{CH}_{3}$ & 4'c & 1.30 & 42 & $-63(1.3)$ & $99^{\mathrm{c}}$ & 47.5 & $+57(0.7)$ & $92^{c}$ & 0.52 & 126 \\
\hline 4 & $\left(\mathrm{CH}_{2}\right)_{3}-\mathrm{CH}_{3}$ & 4'd & 1.15 & 41 & $-54(1.3)$ & $99.7^{\mathrm{c}}$ & 43 & $+50(0.9)$ & $96^{\mathrm{c}}$ & 0.51 & 317 \\
\hline 5 & $\left(\mathrm{CH}_{2}\right)_{7}-\mathrm{CH}_{3}$ & 4'e & 1.30 & 48 & $-42(1.6)$ & $95^{\mathrm{c}}$ & 46 & $+42(1.0)$ & $90^{\mathrm{c}}$ & 0.51 & 119 \\
\hline 6 & $\left(\mathrm{CH}_{2}\right)_{10}-\mathrm{CH}_{3}$ & 4'f & 1.20 & 50 & $-27(2.7)$ & $88^{\mathrm{c}}$ & 45 & $+28(2.3)$ & $99.6^{\mathrm{c}}$ & 0.47 & $>800$ \\
\hline 7 & $\mathrm{CH}_{2}-\mathrm{Ph}$ & 4'g & 1.15 & 47 & $-43(1.5)$ & $99^{\mathrm{c}}$ & 44 & $+41(2.0)$ & $98^{\mathrm{c}}$ & 0.50 & 525 \\
\hline
\end{tabular}

${ }^{\mathrm{a}}$ Isolated yield.

${ }^{\mathrm{b}}$ Enantiomeric excess (ee) was determined by HPLC.

${ }^{\mathrm{c}}$ Enantiomeric excess (ee) was determined by CGC.

silica gel column chromatography. Enentiomeric excesses (ees) of bicycloalkanols $4 * \mathbf{b}-\mathbf{4} * \mathbf{g}$ and 4 'b*-4'g* were determined by gas chromatography on a chiral column (Cydex B) and those of 4'a* samples were determined by HPLC of the corresponding phenylcarbamat on a chiral OD$\mathrm{H}$ column. Enantiomeric excesses of bicyclohex(hept)yl hexanoates $\mathbf{5} \mathbf{b}^{*} \mathbf{- 5} \mathbf{g}^{*}$ and $\mathbf{5}^{\prime} \mathbf{a}^{*-5} \mathbf{5} \mathbf{g}^{*}$ were measured as described above from the corresponding bicyclohex(hjept) an-2-ols isolated after treatment of these esters with $\mathrm{LiALH}_{4}$. The substrate conversion $\mathrm{C}$ and the enantioselectivity factor E were calculated taking the following equations [15], where $\mathrm{ee}_{\mathrm{S}}$ and $\mathrm{ee}_{\mathrm{P}}$ refer to the recovered alcohol substrate and the ester product respectively: $\mathrm{C}=\mathrm{ee}_{\mathrm{S}} /\left(\mathrm{ee}_{\mathrm{S}}+\mathrm{ee}_{\mathrm{P}}\right) ; \mathrm{E}=\ln$ $\left[(1-\mathrm{C})\left(1-\mathrm{ee}_{\mathrm{s}}\right)\right] / \ln \left[(1-\mathrm{C})\left(1+\mathrm{ee}_{\mathrm{s}}\right)\right]$. The results are illustrated in Tables $\mathbf{1}$ and $\mathbf{2}$.

The compounds ethylbicycloheptanol 4'c and butylbicycloheptanol 4'd enriched in the enantiomers $(\mathbf{1} R, \mathbf{2 S}, \mathbf{6 S})[16,17]$ and $(1 S, 2 R, 6 R)$, respectively, were synthesized by cyclopropanation of (S)-3-ethylcyclohex-2-enol $3 \mathbf{c}^{*}$ and of $(R)$-3butylcyclohex-2-enol 3d* prepared by reaction, in the presence of $\mathrm{Li}_{2} \mathrm{CuCl}_{4}$, of EtMgBr and $\mathrm{BuMgBr}$ with the Known optically active $(S)$ - and $(R)$-3-iodocyclohex-2-enols 6, which were available by the method described by Mori and all [18] (Scheme 4).

Determination of the stereochemistry may be obtained by comparison of the specific rotation sign and of the retention time in gas chromatography on a Cydex B column of the $\mathbf{4} \mathbf{c}^{*}$ and $\mathbf{4} \mathbf{d}^{*}$ with those of the optically active bicycloheptanols isolated after the Novozym $^{\circledR}$-catalyzed transesterification with 4'c and 4'd.

\section{CONCLUSION}

In summary, an efficient asymmetric synthesis of optically active endo-bicycloalcanols has been described herein by in vitro enzyme approach. The $E$-values for Novozym ${ }^{\circledR}$ - catalyzed transesterification of isopropenyl hexanoate with endo-bicyclo [4,1,0] heptan-2-ols $(E>60)$ are as high as those obtained with endo-bicyclo $[3,1,0]$ hexan-2ols $(E<20)$.

\section{EXPERIMENTAL SECTION}

\subsection{General}

The spectra of ${ }^{1} \mathrm{H}$ and ${ }^{13} \mathrm{C}$ NMR were carried out on spectrometers Bruker AC-200 (200 and 50.3 $\mathrm{MHz}$, respectively), or on $\mathrm{AC}-250 \quad(250$ and $62.9 \mathrm{MHz}$, respectively). The chemical shifts for carbon and hydrogen are given on the $\delta$ scale relative to TMS (tetramethylsilane, $\delta=0 \mathrm{ppm})$. The abbreviations used are the following: $\mathrm{s}$, singulet; d, doublet; dd, doublet of doublet; t, triplet; $t$, triplet of triplet; q, quadriplet; $\mathrm{m}$, multiplet, and b for broad singlet. $J$ was used to indicate coupling constant in Hertz. The infra-red spectra were recorded on a spectrometer Perkin-Elmer 682. The mass spectra were given on a GC-MS Nermag R10-10 (capillary column: CPSIL5, 25m) with ionization. Flash column chromatography was carried out with Silica Gel 70-230 mesh. The TLC was performed on Merck silica gel $\left(60 \mathrm{~F}_{254}, 0.25 \mathrm{~mm}\right)$. All solvents were obtained dry as follows: the diethyl ether is distilled on $\mathrm{LiALH}_{4}$, the tetrahydrofurane (THF) was distilled from sodium benzophenone ketyl before use, the 1,2dichloroethane and tert-BuOMe is filtered through a short column basic alumina (activity I). A column $\beta$-Cydex $(25 \mathrm{~m}$ $\mathrm{X} 0.25 \mathrm{~mm}$ ) was used for the enantiomeric excess measurements. Cyclohexane-1,3-dione, cyclohex-2-en-1-one and 3-methylcyclohex-2-en-1-one was purchased from the Acros Organics. 


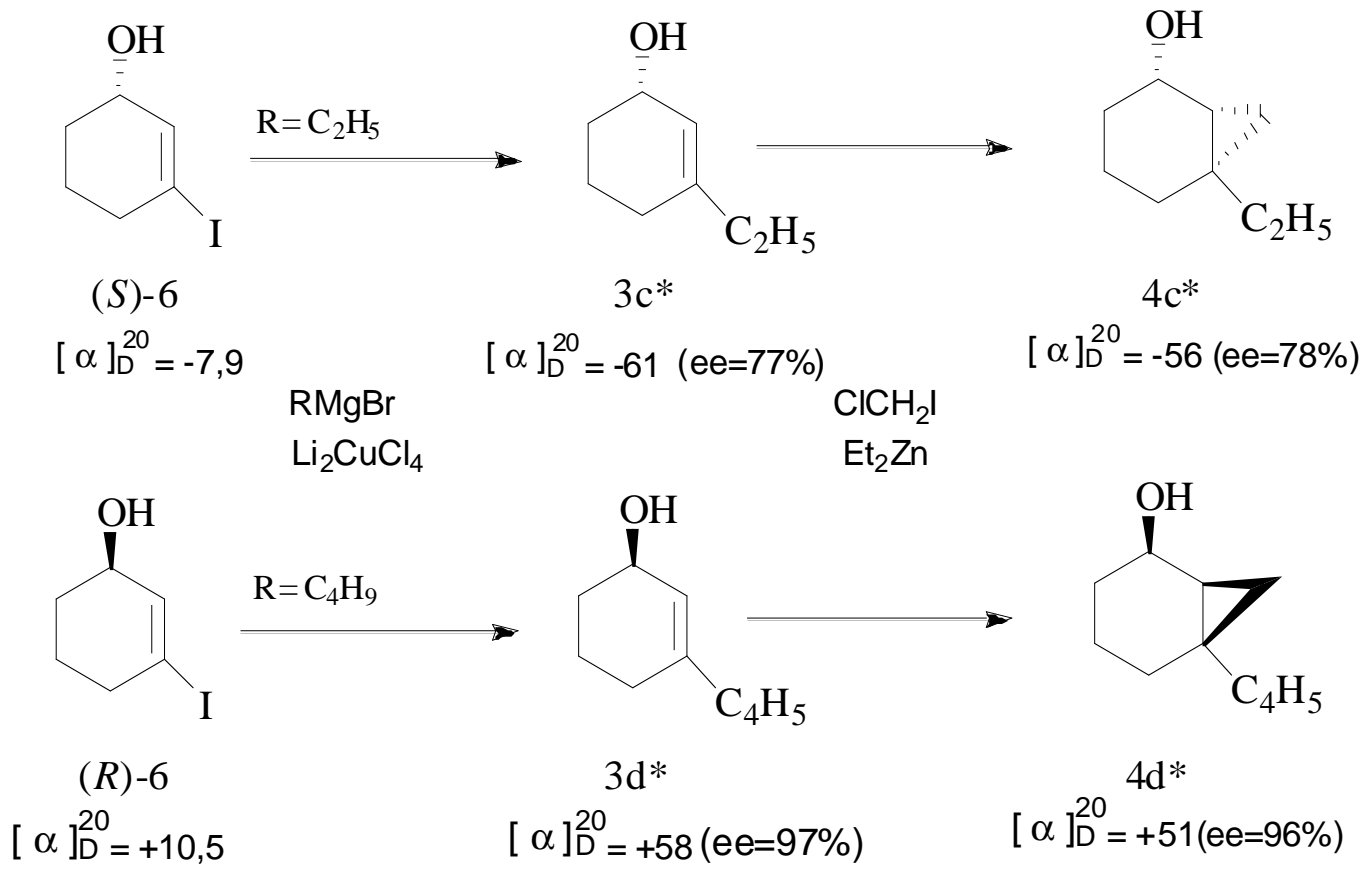

Scheme 4.

\subsection{General Procedure for the Preparation of 3- Ethoxycyclohex-2-en-1-One 1'}

This compound was prepared as described in the literature [11] by treatment of cyclohexane-1,3-dione with ethanol in the presence of $p$-toluenesulfonic acid in a distillation apparatus, but the usual solvent (benzene) was replaced by cyclohexane. With these solvents the boiling point of a binary azeotrope (cyclohexane-ethanol-water: $62.1^{\circ} \mathrm{C}$ or benzene-ethanol-water: $64.6^{\circ} \mathrm{C}$ ) and that of a binary azeotrope (cyclohexane-ethanol: $64.9^{\circ} \mathrm{C}$ or benzene-ethanol: $67.8^{\circ} \mathrm{C}$ ) allow removal the water formed in the reaction then the excess ethanol.

The 3-Ethoxy cyclopent-2-en-1-one $\mathbf{1}$ was prepared according to the same protocol with $\mathbf{1}$ '

The 3-substitud cyclohex-2-enones 2' were prepared from the ethoxycyclohexenone 1' according to literature procedure $[12,13]$.

The 3-substitud cyclopent-2-enones 2 were prepared from the ethoxycyclopentenone $\mathbf{1}$ according to literature procedure $[12,13]$.

Cyclohex-2-en-1-ols 3' were prepared by treatment in methanol of the cyclohexen-2-enones 2' with $\mathrm{NaBH} 4$ in the presence of $\mathrm{CeCl}_{3} .7 \mathrm{H}_{2} \mathrm{O}$ [10].

Cyclopent-2-en-1-ols $\mathbf{3}$ were prepared by treatment in methanol of the cyclopent-2-enones $\mathbf{2}$ with $\mathrm{NaBH} 4$ in the presence of $\mathrm{CeCl}_{3} .7 \mathrm{H}_{2} \mathrm{O}$ [10].

\subsection{General Procedure for the Preparation of Bicyclo $[4,1,0]$ Heptan-2-ol 4'a}

To a solution of $196 \mathrm{mg}$ of cyclohex-2-en -1-ol 3'a ( 2 $\mathrm{mmol})$ in 1,2-dichloroethane $(6 \mathrm{~mL})$ cooled at $0^{\circ} \mathrm{C}$ was added under argon $4 \mathrm{~mL}$ of a $1 \mathrm{M}$ a solution of $\mathrm{Et}_{2} \mathrm{Zn}$ (4 mmol, 2 equiv) in hexane. The reaction mixture was stirred for $15 \mathrm{~min}$ solution at $0^{\circ} \mathrm{C}$ and $600 \mu \mathrm{L}$ of the $\mathrm{ClCH}_{2} \mathrm{I}$ ( $8 \mathrm{mmol}, 4$ equiv) was added dropwise. The reaction mixture was allowed to return to room temperature,. After 15 minutes the argon flow was stopped, the flask was equipped with calcium chloride guard and stirring continued for $1 \mathrm{~h}$. Then the reaction mixture was poured into a saturated ammonium chloride solution and extracted with diethyl ether $\left(3 \times 15 \mathrm{~cm}^{3}\right)$. The combined organic extracts were washed with water and brine, and dried over $\mathrm{Na}_{2} \mathrm{SO}_{4}$. The solvent was removed under vacuum and purified via flash column chromatography eluting with diethyl ether / pentane (20:80) to give 4'a (150 mg, 67\%).

The bicyclo $[4,1,0]$ hexan-2-ols 4'b-g were prepared following the same protocol.

\subsubsection{6-Methylbicyclo [4,1,0]Heptan-2-ol 4'b}

$60 \%$ yield.

${ }^{1} \mathrm{H} \mathrm{RMN}\left(\mathrm{CDCl}_{3}, 250 \mathrm{MHz}\right) \delta 4.22(\mathrm{dd}, J=6.3,12.3 \mathrm{~Hz}$, 1H), 1.51-1.12 (m, 8H), 1.09 (s, 3H), 0.51 (dd, $J=4.9,4.9 \mathrm{~Hz}$, 1H), 0.31 (dd, J=4.9, 8.9 Hz, $1 \mathrm{H}) ;{ }^{13} \mathrm{C} \mathrm{RMN}\left(\mathrm{CDCl}_{3}, 59.3\right.$ MHz) $\delta 67.7,31.8,29.6,29.1,28.3,25.4,22.2,14.0$ [7].

\subsubsection{6-Ethylbicyclo [4,1,0]Heptan-2-ol 4'c}

$98 \%$ yield.

${ }^{1} \mathrm{H} \mathrm{RMN}\left(\mathrm{CDCl}_{3}, 250 \mathrm{MHz}\right.$ ) $\delta 4.19$ (dd, $J=6.2,11.8 \mathrm{~Hz}$, 1H),1.71-1.29 (m, 6H), 1.29-0.94 (m, 4H), 0.90 (bt, $J=7.8 \mathrm{~Hz}$, $3 \mathrm{H}), 0.49$ (dd, $J=4.8,4.8 \mathrm{~Hz}, 1 \mathrm{H}), 0.35(\mathrm{dd}, J=4.8,8.7 \mathrm{~Hz}, 1 \mathrm{H})$; ${ }^{13} \mathrm{C} \mathrm{RMN}\left(\mathrm{CDCl}_{3}, 62.9 \mathrm{MHz}\right) \delta 66.8,33.7,29.6,27.2,25.1$, 24.2, 20.3, 13.4, 10.4; IR (neat): $v_{\max } 3380,3080,3010,2960$, 2840, $1460 \mathrm{~cm}^{-1}$; MS (ESIMS): m/z $140\left(\mathrm{M}^{+}, 1.3\right), 125$ (2.6), 123 (5.5), 122 (22), 111 (39), 107 (29), 94 (26), 93 (100).

\subsubsection{6-Butylbicyclo [4,1,0]Heptan-2-ol 4'd}

$88 \%$ yield.

${ }^{1} \mathrm{H} \mathrm{RMN}\left(\mathrm{CDCl}_{3}, 250 \mathrm{MHz}\right) \delta 4.20(\mathrm{dd}, J=6.2,12.0 \mathrm{~Hz}$, $1 \mathrm{H}), 1.73-0.96$ (m, 14H), 0.89 (bt, $j=7.6 \mathrm{~Hz}, 3 \mathrm{H}), 0.48$ (dd, $J=4.7,4.7 \mathrm{~Hz}, 1 \mathrm{H}), 0.34(\mathrm{dd}, J=4.7,8.7 \mathrm{~Hz}, 1 \mathrm{H}) ;{ }^{13} \mathrm{C} \mathrm{RMN}$ $\left(\mathrm{CDCl}_{3}, 62.9 \mathrm{MHz}\right): \delta 66.8,40.9,29.6,28.7,27.6,25.3$, 
23.1, 22.7, 20.2, 14.0, 13.7 ; IR (neat): $v_{\max } 3400,3060$, 3000, 2960, 2840, $1460 \mathrm{~cm}^{-1}$; MS (ESIMS): m/z $168\left(\mathrm{M}^{+}\right.$, 0.9), 151 (3.3), 150 (13), 125 (9.1), 111 (46), 94 (23), 93 (99), 82(58), 79 (100).

\subsubsection{6-Hexylbicyclo [4,1,0]Heptan-2-ol 4'e}

$60 \%$ yield.

${ }^{1} \mathrm{H} \mathrm{RMN}\left(\mathrm{CDCl}_{3}, 250 \mathrm{MHz}\right) \delta 4.20(\mathrm{dd}, J=6.3,11.82 \mathrm{~Hz}$, $1 \mathrm{H}), 1.73-0.96(\mathrm{~m}, 22 \mathrm{H}), 0.8$ (bt, $j=7.5 \mathrm{~Hz}, 3 \mathrm{H}), 0.49$ (dd, $J=4.6,4.6 \mathrm{~Hz}, 1 \mathrm{H}), 0.35(\mathrm{dd}, J=4.6,8.5 \mathrm{~Hz}, 1 \mathrm{H}) ;{ }^{13} \mathrm{C} \mathrm{RMN}$ $\left(\mathrm{CDCl}_{3}, 62.9 \mathrm{MHz}\right): \delta 66.8,41.3,31.8,29.8,29.7,29.6$, 29.3, 27.7, 26.5, 25.5, 23.3, 22.6, 20.3, 14.0, 13.7 ; IR (neat): $v_{\max }$ 3360, 3060, 3000, 2960, 2840, $1460 \mathrm{~cm}^{-1} ; \mathrm{MS}$ (ESIMS): m/z $224\left(\mathrm{M}^{+}, 15\right), 207$ (9.3), 206 (21), 111 (25), 97 (19), 94 (21), 93 (64), 82 (36).

\subsubsection{6-Undecylbicyclo $[4,1,0]$ Heptan-2-ol 4'f}

$60 \%$ yield.

${ }^{1} \mathrm{H}$ RMN $\left(\mathrm{CDCl}_{3}, 250 \mathrm{MHz}\right) \delta 4.18(\mathrm{dd}, J=6.2,11.08$ $\mathrm{Hz}, 1 \mathrm{H}), 1.71-0.95$ (m, 26H), 0.89 (bt, $J=7.5 \mathrm{~Hz}, 3 \mathrm{H}), 0.45$ $(\mathrm{dd}, \mathrm{J}=4.7,4.7 \mathrm{~Hz}, 1 \mathrm{H}), 0.34(\mathrm{dd}, J=4.7,8.6 \mathrm{~Hz}, 1 \mathrm{H}) ;{ }^{13} \mathrm{C}$ RMN $\left(\mathrm{CDCl}_{3}, 62.9 \mathrm{MHz}\right): \delta 67.1,41.3,31.9,29.9,29.8$, 29.7, 29.65, 29.6, 29.5, 29.3, 27.8, 26.6, 25.6, 23.4, 22.7, 20.3, 14.0, 13.6; IR (neat): $v_{\max } 3370,3070,3005,2960$, 2840, $1460 \mathrm{~cm}^{-1}$; MS (ESIMS): m/z 247 (4.2), 92 (26), 91 (41), 82 (7.9), 79 (100).

\subsubsection{6-Benzylbicyclo [4,1,0]Heptan-2-ol 4'g}

$66 \%$ yield.

${ }^{1} \mathrm{H} \mathrm{RMN}\left(\mathrm{CDCl}_{3}, 200 \mathrm{MHz}\right) \delta$ 7.43-7.16 (m, 5H), 4.27 (dd, J=4.8, 8.5 Hz, 1H), 2.63 (s, 2H), 1.72-0.96 (m,8H), 0.60 $(\mathrm{dd}, J=6.3 \mathrm{~Hz}, 2 \mathrm{H}) ;{ }^{13} \mathrm{C} \mathrm{RMN}\left(\mathrm{CDCl}_{3}, 62.9 \mathrm{MHz}\right): \delta 139.8$, 129.0, 128.0, 125.9, 66.4, 46.1, 29.7, 27.5, 25.1, 23.4, 19.7, 12.8 ; IR (neat): $v_{\max } 3360,3080,3060,3020,3000,2960$, 2840, $1450 \mathrm{~cm}^{-1}$; MS (ESIMS): m/z $202\left(\mathrm{M}^{+}, 0.3\right), 185$ (2.7), 184 (16), 111 (11), 94 (5), 93 (59), 91 (100), 77 (39).

The bicyclo $[3,1,0]$ hexan-2-ols $\mathbf{4 b - g}$ were prepared according to the same protocol with 4 'a

\subsubsection{5-Butylbicyclo [3,1,0]Hexan-2-ol (4d)}

$51 \%$ yield.

${ }^{1} \mathrm{H} \mathrm{RMN}\left(\mathrm{CDCl}_{3}, 200 \mathrm{MHz}\right) \delta 4.52(\mathrm{~m}, 1 \mathrm{H}), 1.96(\mathrm{~m}$, $1 \mathrm{H}), 1.72(\mathrm{~m}, 1 \mathrm{H}), 1.63(\mathrm{~m}, 1 \mathrm{H}), 1.50(\mathrm{~m}, 2 \mathrm{H}), 128(\mathrm{~m}, 7 \mathrm{H})$, $1.10(\mathrm{~m}, 1 \mathrm{H}), 0.92(\mathrm{t}, J=4.7 \mathrm{~Hz}, 3 \mathrm{H}), 0.34(\mathrm{~m}, 1 \mathrm{H}) ;{ }^{13} \mathrm{C} \mathrm{RMN}$ $\left(\mathrm{CDCl}_{3}, 62.9 \mathrm{MHz}\right) \delta 72,8,40,3,32,9,32,0,28,5,27,8,23,7$, 20,2, 14,0, 12,7 ; IR (neat): $v_{\max } 3380,3060,3010,2960$, 2840, $1460 \mathrm{~cm}^{-1}$; MS (ESIMS): m/z 154 (2.10), 125 (17.85, 97 (55.24), 85 (27.76), 79 (76.20), 70 (100).

\subsubsection{5-Hexylbicyclo [3,1,0]Hexan-2-ol (4e)}

$50 \%$ yield.

${ }^{1} \mathrm{H}$ RMN $\left(\mathrm{CDCl}_{3}, 250 \mathrm{MHz}\right) \delta 4.59-4.44(\mathrm{~m}, 1 \mathrm{H}), 2.01-1.84$ $(\mathrm{m}, 1 \mathrm{H}), 1.84-1.68(\mathrm{~m}, 1 \mathrm{H}), 1.55-1.45(\mathrm{~m}, 2 \mathrm{H}), 1.45-1.19$ $(\mathrm{m}, 11 \mathrm{H}), 1.19-1.00(\mathrm{~m}, 1 \mathrm{H}), 0.87(\mathrm{t}, J=6.84 \mathrm{~Hz}, 3 \mathrm{H}), 0.35-$ $0.26(\mathrm{~m}, 1 \mathrm{H}) ;{ }^{13} \mathrm{C} \mathrm{RMN}\left(\mathrm{CDCl}_{3}, 62.9 \mathrm{MHz}\right) \delta 72,8,40,6$, $32,9,32,5,32,0,30,6,28,5,25,6,23,1,20,2,14,0,12,7$; IR (neat): $v_{\max } 3360,3020,3000,2960,2840,1460 \mathrm{~cm}^{-1}$; MS (ESIMS): m/z $128\left(\mathrm{M}^{+}, 3,82\right), 165$ (8), 164 (21), 97 (23), 80 (17), 79 (100), 67 (11), 66 (21).
4.4. General Procedure for the Enzymatic Resolution of Endo-Bicyclo [4,1,0]Heptan-2-ol 4'a

Bicyclo [4,1,0]heptan-2-ol (112 mg, 1 mmol) 4'a was dissolved in tert-BuOMe $(4 \mathrm{~mL})$ in a flask equipped with a magnetic sirrer. To this solution $162 \mathrm{mg}$ of Novozym ${ }^{\circledR}$ and $167 \mathrm{mg}$ of isopropenyl hexanoate ( $1.07 \mathrm{mmol}, 1.07$ equiv) was added and the reaction mixture was stirred at $37^{\circ} \mathrm{C}$. The reaction was monitored by TLC; at around $50 \%$ conversion, the reaction was stopped by removing the enzyme by filtration, and the solid was washed several times with tertBuOMe. After concentration under reduced pressure and then the residue was purifed on a silica gel column chromatography (pentane:diethyl ether:70/30) to give the bicyclo $[4,1,0]$ heptane-2-yl hexanoate $\mathbf{5}^{\prime} *(107 \mathrm{mg}, 51 \%)$ and the alcohol $4 *(46 \mathrm{mg}, 41 \%)$.

The bicycloheptyl hexanoate $\mathbf{5}^{*}$ was then treated at $0^{\circ} \mathrm{C}$ in lithium aluminium hydrure. After stirring for $1 \mathrm{~h}$ at room temperature, wet $\mathrm{Na}_{2} \mathrm{SO}_{4}$ was added in order to obtain a clear supernant solution. After filtration, the solution was concentracted under reduced pressure and the optically active coumpound bicyclo [4,1,0]heptan-2-ol (90\% yield) was separated from the hexan-1-ol by silica gel flashchromatographed (20:80 to 50:50 diethyl ether in $n$-pentane).

The transesterifications with bicycloheptanols $\mathbf{4}$ 'b-g were made following the same procedure.

The transesterifications with bicyclohexanols $4 \mathbf{b}, \mathbf{d}-\mathbf{e}, \mathbf{g}$ ware obtained according to the same protocol with 4'a-g.

4.5. General Procedure for the Preparation of 3Ethylcyclohex-2-en-1-ol 3c*

To a solution of the soluble $\mathrm{Li}_{2} \mathrm{CuCl}_{4}(84 \mathrm{mg}, 0.38 \mathrm{mmol}$, 0.15 equiv) in THF $(4 \mathrm{~mL})$ at $-20^{\circ} \mathrm{C}$ under argon, $10,5 \mathrm{~mL}$ of a $1 \mathrm{M}$ solution of EtMgBr in THF $(10.5 \mathrm{~mL}, 4$ equiv) and 586 $\mathrm{mg}$ of (-)-3-iodocyclohex-en-1-ol 6 [18] in THF(4 mL) was added. After sterring for 14 hours at $-20^{\circ} \mathrm{C}$ and 4 hours at $20^{\circ} \mathrm{C}$, the reaction mixture was poured into a saturated ammonium chlorur solutione and extracted with diethyl ether $(3 \times 30 \mathrm{~mL})$. The combined organic extract was washed with water and dried over anhydrous $\mathrm{Na}_{2} \mathrm{SO}_{4}$. The solvent was evaporated under reduced pressure and the crude product was purified on a silica gel column chromatography to obtain the (-)-3-ethycyclohex-en-1-ol 3c* 219mg (66\% yield) using diethyl ether/n-pentane (10:90) as eluent. Enantiomeric excess $(\mathrm{ee}=77 \%)$ was determined by GLC analysis using $\beta$-Cydex chiral column $\left(\mathrm{p}=0.8 \mathrm{bar}, 85^{\circ} \mathrm{C}\right)$. The retention time for the $(S)-3 \mathbf{c}^{*}$ is $27 \mathrm{~min}$ and for $(R)-\mathbf{3 c} *$ is 30 $\min$.

4.6. General Procedure for the Preparation of 3Butylcyclohex-2-en-1-ol 3d*

This product was obtained from (+)-3-iodocyclohex-2en-1-ol 6 [1718 and $\mathrm{BuMgBr}$, according to the same previous protocol, in $199 \mathrm{mg}$ ( $72 \%$ yield). Enantiomeric excess $(e=97 \%$ ) was determined by GLC analysis using $\beta$ Cydex chiral column $\left(\mathrm{p}=0.8 \mathrm{bar}, 85^{\circ} \mathrm{C}\right)$. The retention time for the $(S)-\mathbf{3} \mathbf{d}^{*}$ is 39 mins and for $(R)-\mathbf{3} \mathbf{d}^{*}$ is $40 \mathrm{mins}$.

\section{ACKNOWLEDGEMENTS}

We thank the Carbocycles laboratory of Paris-South University (Orsay) for the analysis experiments of the products. 


\section{REFERENCES}

[1] (a) Roberts, S. M. preparative biotransformations. Perkin Trans. 1 1999, 1, 1-21; (b) Jones, J. B.; Desantis, G. Toward Understanding and Tailoring the Specificity of Synthetically Useful Enzymes. Acc. Chem. Res. 1999, 32, 99; (c) Stecher, H.; Faber, K. Biocatalytic Deracemization Techniques: Dynamic Resolutions and . Stereoinversions. Synthesis 1997, 1; (d) Schoffers, E.; Golebiowski, A.; Johnson, C. R. Enantioselective synthesis through enzymatic asymmetrization. Tetrahedron 1996, 51, 3769; (e) Santaniello, E.; Ferrabosh, P.; Grisenti, P.; Manzocchi, A. The Biocatalytic Approch to the Preparation of Enantiomerically Pure Chiral Building Bloks. Chem. Rev. (Washington, D. C.) 1992, 92, 1071; (f) Gupta, M. N. Enzyme function in organic solvents. Eur. J. Biochem. 1992, 203, 25; (g) Kaslaukas, R. J.; Weissfloch, A. N. E.; Rappaport, A. T. ; Cuccia, L. A. A rule to predict which enantiomer of a secondary alcohol reacts faster in reactions catalyzed by cholesterol esterase, lipase from Pseudomonas cepacia, and lipase from Candida rugosa. J. Org. Chem. 1991, 56, 2656; (h) Zhu, L. M.; Tedford, M. C. Application of Pig Liver Esterases (PLE) in Asymetric Synthesis. Tetrahedron 1990, 46, 6587; (i) Chen, C. S.; Sih, C. J. General Aspects and Optimization of Enantioselective Biocatalysis in Organic Solvents: The Use of Lipases [New Synthetic Methods. Angew. Chem., Int. Ed. 1989, 28, 695; ( j) Whitesides, G. M.; Wong, C. H. Enzymes as Catalysts in Synthetic Organic Chemistry [New Synthetic Methods. Angew. Chem., Int. Ed. 1985, 24, 617; (k) Faber, K. In Biotransformations in Organic Chemistry; Springer-Verlag; Berlin, 1997; (1) Stecher, H.; Faber, K. Biocatalytic Deracemization Techniques: Dynamic Resolutions and Stereoinversions. Synthesis 1997, 1; (m) Azerad, R. Application of biocatalysts in organic synthesis. Bull. Soc. Chim. Fr. 1995, 132, 17; (n) Lemke, K.; Lemke, M.; Theil, F. A Three-Dimensional Predictive Active Site Model for Lipase from Pseudomonas cepacia. J. Org. Chem. 1997, 62, 6268; (o) Itoh, T.; Kuroda, K.; Tomasada, M.; Takagi, Y. Design of alpha.-alkyl-betahydroxy esters suitable for providing optical resolution by lipase hydrolysis. J. Org. Chem. 1991, 56, 797; (p) Grabuleda, X.; Jaime, C.; Guerrero, A. Estimation of the lipase PS(Pseudomonas cepacia) active site dimentions based on molecular mechanics calculations. Tetrahedron:Asymmetry 1997, 8, 3675.

[2] (a) Handilou, E.; Kokkini, S.; Kokkalou, E. Volatile constituents of Achillea abrotanoides in relation to their infrageneric variation. Biochem. Syst. Ecol. 1992, 20, 33-40; (b) Handilou, E.; Kokkalou, E.; Kokkini, S. Volatile Constituents of Achillea grandifolia. Planta Med. 1992, 58, 105-107; (c) Komaitis, M. E.; IfantiPapatragianni, N.; Melissari-Panagiotou, E. Composition of the essential oil of marjoram (Origanum majorana L.). Food Chem. 1992, 45, 117-118; (d) Tori, M.; Hamaguchi, T.; Aoki, M.; Sono, M.; Asakawa, Y. Isolation, structure, and synthesis of chenopodanol and the absolute configuration of chenopodene and chenopodanol Y. Can. J. Chem. 1997, 75, 634-640; (e) Miyamoto, T.; Ebisawa, Y.; Higuchi, R. Aplyparvunin, a bioactive acetogenin from the sea hare Aplysia parvula. Tetrahedron Lett. 1995, 36, 6073-6074.

[3] For an example of an optically active bicyclo [n,1,0]alkan-2-ol isolated from a natural source see: Hiyamoto, T.; Ebisawa, Y.; Higuchi, R. Aplyparvunin, a bioactive acetogenin from the sea hare Aplysia parvula. Tetrahedron Lett. 1995, 36, 6073-6074.

[4] (a) Hill, R. K.; Morgan, J. W. Absolute configuration of 2cyclohexen-1-ol. J. Org. Chem. 1968, 33, 927-928; (b) Barbachyn, M. R.; Johnson, C. R.; Glick, M. D. Synthesis and absolute configuration of (-)-rothrockene, a non-head-to-tail monoterpene. $J$. Org. Chem. 1984, 49, 2746-2748.

[5] Clive, D. L. J.; Daigneault, S. Use of radical ring opening for introduction of alkyl and substituted alkyl groups with stereochemical control: a synthetic application of cyclopropylcarbinyl radicals. J. Org. Chem. 1991, 56, 3801-3814.
Hlaimia, F.; Djerourou, A. H. Dédoublement enzymatique de bicycloalcan-2-ols optiquement actifs et essais de cyclopropanation sélective sur le 3-(but-3-ényl)cyclohex-2-ène1-ol. C. R. Chimie. 2006, 9, 141-147.

[7] (a) Winstein, J.; Sonneberg, J.; Devries, L. The TrisHomocyclopropenyl Cation $1^{1}$. J. Am. Chem. Soc. 1959, 81, 65236524; (b) Dauben, W. G.; Berzin, G. H. The Preparation of Cyclic Cyclopropylcarbinols. J. Am. Chem. Soc. 1963, 85, 468-472; For a review on "Substrate-directable chemical reactions" where are reported various example of hydroxyl directed cyclopropanation of allylic alcohol, see: (c) Hoveyda, A. H.; Evans, D. A.; Fu, G. C. Substrate-directable chemical reactions. Chem. Rev. 1993, 93, $1307-1370$.

[8] (a) Miyano, S.; Izumi, Y.; Fujii, H.; Hashimoto, H. Preparation of Trimethylsilyloxycyclopropanes from Enol Silyl Ethers by Means of the Diethylzinc/Chloroiodomethane/Oxygen System. Synthesis 1977, 700-701. (b) Denmark, S. E.; Edwards, J. P. A comparison of (chloromethyl)- and (iodomethyl)zinc cyclopropanation reagents. $J$. Org. Chem. 1991, 56, 6974-6981.

[9] Denmark, S. E.; Edwards, J. P. A comparison of (chloromethyl)and (iodomethyl)zinc cyclopropanation reagents. J. Org. Chem. 1991, 56, 6974-6981. In these reactions the exo diastereoisomers were not noticed by NMR spectroscopy.

[10] Luche, J.-L. Lanthanides in organic chemistry. 1. Selective 1,2 reductions of conjugated ketones. J. Am. Chem. Soc. 1978, 100, 2226-2227.

[11] Chenera, B.; Chuang, C-P.; Hart, D. J.; Lai, C.-S. Synthetic approaches to the axane family of sesquiterpenoids. Total synthesis of (dl)-axamide-4, (dl)-axisonitrile-4, and (dl)axisothiocyanate-4. J. Org. Chem. 1992, 57, 2018-2029.

[12] Woods, G. F.; Tucker, I. W. The Reaction of $\beta$-Cyclohexanedione (Dihydroresorcinol) and its Ethyl Enol Ether with Phenylmagnesium Bromide. J. Am. Chem. Soc. 1948, 70, 21742177.

[13] Mori, K.; Uchida, M.; Matsui, M. Synthesis of aliphatic insect pheromones from alicyclic starting material: (Z)-6-heneicosen-11one and (Z)-8-dodecenyl acetate. Tetrahedron 1977, 33, 385-387; Tetrahedrofurane was probably released in this reaction which was under investigation.

[14] (a) Kazlauskas, R.J.; Weissfl och, A.N.E.; Rappaport, A.T .; Cuccia, L.A. A rule to predict which enantiomer of a secondary alcohol reacts faster in reactions catalyzed by cholesterol esterase,lipase from Pseudomonas cepacia, and lipase from Candida rugosa. J. Org. Chem. 1991, 56, 2656; (b) Kazlauskas, R.J.; Weissfl och, A.N.E. A structure-based rationalization of the enantiopreference of subtilisin toward secondary alcohols and isosteric primary amines. J. Mol. Catal. B- Enzym. 1997, 3, 65.

[15] Chen, C.-S.; Fujimoto, Y.; Girdaukas, G and Sih, C.J. Quantitative analyses of biochemical kinetic resolutions of enantiomers. J. Am. Chem. Soc. 1982, 104, 7294

[16] Aranda, G.; Bertrane, M.; Azerad, R.; Maurs, M. Microbial synthesis of optically pure (R)-2,4,4-trimethyl-3-(2'-hydroxyethyl)cyclohex-2-en-1-ol, a new and versatile chiral building block for terpene synthesis. Tetrahedron: Asymmetry 1995, 6, 675-678.

[17] (a) Carrea, G.; Danieli, B.; Palmisano, G.; Riva, S.; Santagostino, M. Lipase-mediated resolution of 2- cyclohexen-1-ols as chiral buildingblocks en route to eburnane alkaloids. Tetrahedron: Asymmetry 1992, 33, 775-784; (b) Satoh, T.; Motohashi, S.; Tokutake, N.; Yamakawa, K. A Novel Synthesis Including Asymmetric Synthesis of $\alpha, \beta$-Unsaturated $\gamma$-Hydroxy Carbonyl Compounds from Enones with Carbon Homologation. Bull. Chem. Soc. Jpn. 1992, 65, 2966-2973.

[18] Mori, K.; Tamada, S.; Uchida, M.; Mizumachi, N.; Tachibana, Y.; Matsui, M. Synthesis of optically active forms of seudenol, the pheromone of douglas fir beetle. Tetrahedron 1978, 34, 1901-1905. 